\title{
Pemanfaatan Teknologi Terestrial Laser Scanner \\ Untuk Perekaman Data dan Pendokumentasian Tiga Dimensi (3D) Lukisan Cadas Pada Gua-Gua Prasejarah di Indonesia (Studi Kasus : Kawasan Karst Sangkulirang Mangkalihat Kalimantan Timur)
}

\author{
Brahmantara \\ Balai Konservasi Borobudur \\ Email : bramantarayk@gmail.com
}

\begin{abstract}
Abstrak : Perkembangan teknologi perekaman data cagar budaya khususnya luksian Cadas (Rock Art) telah berkembang dengan pesat seiring dengan perkembangan teknologi digital. Teknik dan metode perekaman data cagar budaya berkembang dari teknik sederhana sampai dengan teknologi mutakhir berbasis digital dengan format tiga dimensi (3D). Teknologi Terestrial Laser Scanner merupakan perangkat digital dengan sasaran perekaman tiga dimensi (3D).

Dalam penelitian ini penerapan Teknologi Terestrial Laser Scanner digunakan untuk merekam data geometri gua dan detail lukisan cadas (Rock Art) pada kawasan Karst Sangkulirang mangkalihat Kutim Kalimantan Timur. Proses registrasi dari masing masing posisi pemindaian (scan world) menghasilkan tingkat akurasi data yang sangat tinggi dengan rata-rata eror dibawah $2 \mathrm{~mm}$.

Dari hasil pengolahan data didapatkan beberapa output dan beberapa produk akhir yang sangat signifikan seperti gambar 2D, citra 3D, DSM (digital surface model), data kontur dengan interval sampai $25 \mathrm{~cm}$, animasi dalam format avi dan informasi publikasi dalam bentuk virtual tour $360^{\circ}$. Dari hasil analisa data tingkat akurasi, jumlah output yang dihasilkan dan alokasi waktu yang dibutuhkan untuk proses perekaman data metode perekaman data dengan Teknologi Terestrial Laser Scanner ini sangat efektif untuk digunakan dalam perekaman data dan pendokumentasian cagar budaya khususnya lukisan cadas (rock art).
\end{abstract}

Kata kunci : Terestrial Laser Scanner, lukisan cadas (Rock Art), tiga dimensi (3D)

Abstract : The development of cultural heritage data recording technologies, especially Rock paintings (rock art) has grown rapidly along with the development of digital technology. Techniques and methods of data recording of cultural heritage evolved from simple techniques to digital-based cutting-edge technology with three-dimensional format (3D). Terrestrial Laser Scanner technology is a digital device with a target of three-dimensional (3D) recording technology.

In this study the application of Terrestrial Laser Scanner technology is used to record the geometry data on the cave and rock paintings detail (rock art) in the Karst region of Sangkulirang Mangkalihat East Kutai Regency, East Kalimantan. The process of registration of each scaning position (scan world) produce a level of data accuracy which is very high with an average error below $2 \mathrm{~mm}$.

From the data processing activity obtained multiple outputs and some of the final product is very significant as $2 \mathrm{D}$ images, 3D images, DSM (digital surface model), contour data at intervals of up to $25 \mathrm{~cm}$, the animation in avi format and publication information in the form of virtual tour $360^{\circ}$. From the data analysis and accuracy rate, the amount of output produced and the allocation of time required to process the data recording method using Terrestrial Laser Scanner technology is very effective to be used in data recording and documentation of cultural heritage, especially rock painting (rock art).

Keywords: Terrestrial Laser Scanner, rock paintings (rock art), three-dimensional (3D)

\section{PENDAHULUAN}

\section{Latar Belakang}

Indonesia merupakan negara kepulauan yang terdiri dari berbagai macam suku bangsa. Disamping keanekaragaman suku bangsa yang ada, pulau Indonesia juga terdiri dari berbagai macam topografi kepulauan dengan karakteristik yang berbeda-beda, ada pulau dengan gugusan gunung dan ada pulau yang dikelilingi oleh lautan. Tinggalan budaya yang tersebar dari sabang sampai merauke merupakan kekayaan bangsa yang tidak ternilai harganya. Salah satu tinggalan dari masa prasejarah yang mempunyai nilai keagungan luar biasa, refleksi dari nilai seni masa lalu adalah lukisan cadas (Rock Art) pada gua prasejarah di Kawasan Karst Sangkulirang Mangkalihat Kalimantan Timur. Berbagai macam penelitian dengan berbagai macam latar belakang keilmuan sudah dilakukan untuk mengetahui lebih dalam tentang lukisan cadas (Rock Art) yang dibuat oleh nenek moyang prasejarah.

Pemerintah melalui Direktorat Jenderal 
Kebudayaan dan Unit Pelaksana Teknisnya di daerah yaitu BPCB (Balai Pelestarian Cagar Budaya) Kalimantan Timur terus berusaha untuk melestarikan keberadaan tinggalan prasejarah tersebut, tidak hanya berhenti pada tataran pelestarian, BPCB Kaltim terus melakukan usaha pelestarian dengan mengajukan lukisan cadas (Rock Art) pada gua prasejarah di Kawasan Karst Sangkulirang Mangkalihat Kalimantan Timur tersebut sebagai Situs Warisan Dunia (World Heritage Sites).

Data lukisan cadas (Rock Art) yang ada di Kawasan Karst Sangkulirang Mangkalihat sangatlah banyak dengan keanekaragaman lukisan pada masing-masing gua. Proses perekaman data dan pendokumentasian lukisan cadas (Rock Art) sangat diperlukan untuk mendukung proses pelestarian dan mendukung pengajuan sebagai warisan dunia (World Heritage). Kemajuan teknologi berbasis digital untuk pemetaan dan penggambaran saat ini berkembang cukup pesat dan luas. Salah satu perangkat yang menggunakan teknologi tinggi dan kemampuan digital untuk merekam data adalah Terestrial Laser Scanner. Pemanfaatan teknologi Terestrial Laser Scanner mampu memberikan data dan akurasi ketelitian yang sangat tinggi dalam format dua dimensi (2D) dan tiga dimensi (3D).

Teknologi Terestrial Laser Scanner saat ini sudah mengalami pengembangan fungsi di berbagai bidang, salah satunya untuk perekaman data Cagar Budaya, dibandingkan alat dan metode lainnya, teknologi ini mempunyai beberapa kelebihan yaitu kecepatan perekaman data yang tinggi, tingkat akurasi yang baik dan kenampakan data hasil perekaman yang sesuai dengan kondisi asli obyek (Pflipsen, 2006).

Metode pengukuran perangkat Terestrial Laser Scanner ini hampir sama dengan metode pada Fotogrametri rentang dekat (close range photogrammetry), hal yang membedakan adalah jarak kemampuan alat merekam obyek. Pada perangkat long range Laser Scanner kemampuan yang dimiliki oleh alat mampu merekam jarak sampai dengan $1 \mathrm{~km}$ dengan hasil yang didapatkan berupa data tiga dimensi (3D) dalam bentuk titik-titik awan (point clouds).

\section{Rumusan Masalah}

Rumusan masalah yang ada dari uraian latar belakang penelitian ini adalah sebagai berikut :
1. Apakah metode perekaman data dan pendokumentasian lukisan cadas (rock art) pada gua prasejarah dengan teknologi Terestrial Laser Scanner tiga dimensi (3D) merupakan solusi yang ideal, yang hasilnya bisa dipertanggungjawabkan sebagai data acuan (reference) untuk kegiatan preservasi ?

2. Seberapa efektif teknologi Terestrial Laser Scanner tiga dimensi (3D) ini bisa digunakan untuk perekaman data dan pendokumentasian secara detail obyek lukisan cadas (rock art) pada gua prasejarah di kawasan Karst Sangkulirang Mangkulihat Kalimantan Timur?

\section{Ruang Lingkup Penelitian}

Ruang lingkup pada penelitian ini dibatasi pada beberapa hal yaitu :

1. Proses perekaman data dan pendokumentasian dilakukan pada lukisan cadas (rock art) gua prasejarah di kawasan Karst Sangkulirang Mangkalihat, Propinsi Kalimantan Timur.

2. Perekaman data dan pendokumentasian yang dilakukan meliputi geometri gua dan detil lukisan cadas (rock art).

3. Proses perekaman data dan pendokumentasian menggunakan perangkat Terestrial Laser Scanner tiga dimensi (3D) Leica Scan Station C 10.

\section{Tujuan Penelitian}

Adapun tujuan yang ingin dicapai dalam pelaksanaan penelitian ini adalah sebagai berikut :

1. Mengaplikasikan teknologi Terestrial Laser Scanner tiga dimensi (3D) untuk perekaman data dan pendokumentasian lukisan cadas (rock art) pada gua prasejarah.

2. Mendapatkan metode perekaman data dan pendokumentasian cagar budaya yang cepat, tepat dan efektif.

3. Mendapatkan data-data geometri gua, dan detail lukisan cadas (rock art) sebagai data acuan awal

\section{Manfaat Penelitian}

Manfaat dari pelaksanaan penelitian ini adalah penggunaan aplikasi teknologi Terestrial Laser Scanner tiga dimensi (3D) yang diharapkan mampu dijadikan sebagai satu metode yang tepat dan cepat untuk perekaman data 

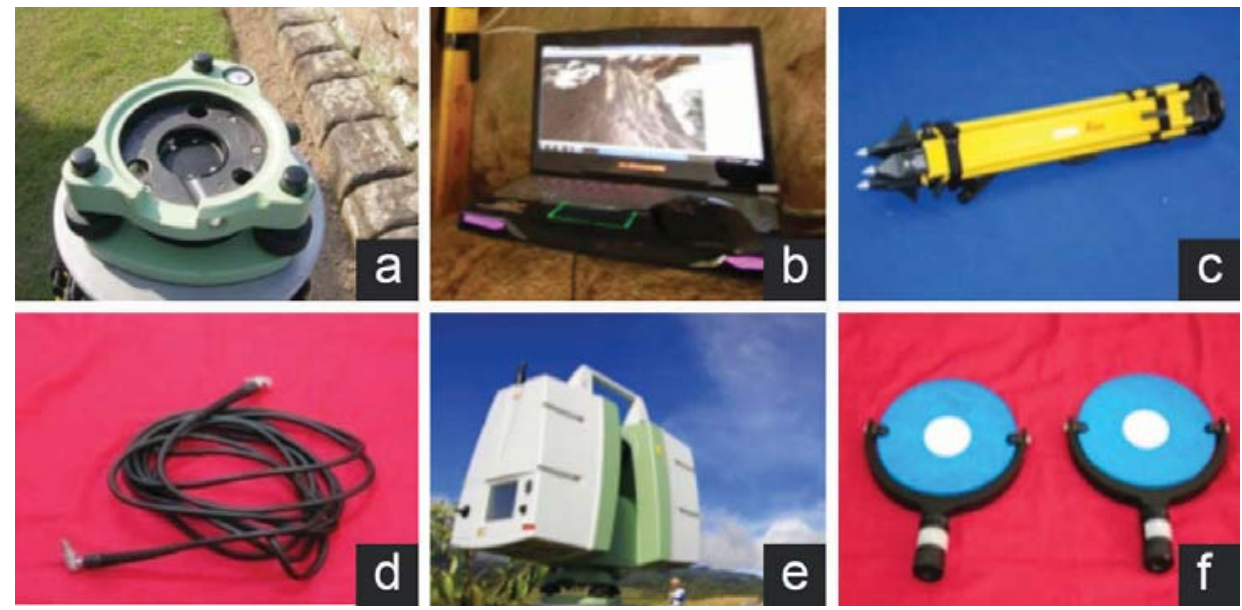

Gambar 1. Perangkat perekaman 3D Laser scanner (a) tribach, (b) laptop, (c) tripod, (d) kabel koneksi data, (e) scanning head, (f) target scan

pendokumentasian cagar budaya lukisan cadas (rock art) gua prasejarah yang membutuhkan ketelitian, kecepatan, data detail dan tingkat akurasi yang tinggi.

\section{Metode Penelitian}

Alat

Peralatan yang digunakan dalam proses perekaman data dilapangan untuk analisis data penelitian terdiri dari perangkat keras (hardware) dan perangkat lunak (software), dengan rincian sebagai berikut :

1. Laser Scanner scan station C10 Leica

2. External kamera Canon Eos 70D

3. Bracket external kamera

4. Tripod

5. Target 3 inchi dan 6 inchi

6. Tribach

7. Laptop work station (MSI)

8. Software Cyclone 9.0

9. Software Autocad 2015

10. Software 3D Reshaper.

\section{Metode Pelaksanaan}

Metode yang digunakan dalam prose perekaman data tiga dimensi (3D) menggunakan Laser Scanner dibagi menjadi 4 tahap, yang terdiri dari :

\section{Tahap persiapan}

Pada tahap persiapan awal penelitian ini kegiatan yang dilakukan meliputi studi pustaka/literatur terkait data situs/obyek yang menjadi sasaran perekaman data. Dalam tahapan persiapan ini dibutuhkan arkeolog, surveyor dan juga juru pelihara sebagai personil yang menangani langsung situs/ obyek dilapangan. Arkeolog memberikan informasi tentang sejarah situs/obyek, sehingga memberikan gambaran tentang hal-hal penting pada bagian apa saja yang harus direkam secara lebih detail. Juru pelihara situs membantu dalam proses perekaman dilapangan

2. Tahap perekaman data di lapangan

Merupakan tahapan yang dilakukan pada obyek penelitian yaitu pada Gua Mengkuris di kecamatan Karangan Kabupaten Kutai Timur, Propinsi Kalimantan Timur.

Dalam tahapan perekaman data dilapangan ini dibagi menjadi beberapa aktivitas yaitu :

a. Survey lokasi untuk penentuan titik berdiri alat

b. Proses perekaman data (pemindaian tiga dimensi (3D)

\section{Tahap Pengolahan data}

Proses pengolahan data dilakukan di lapangan dan di laboratorium. Pengolahan data di lapangan sebagai koreksi awal apabila ada data yang kurang, sehingga bisa cepat dilengkapi dan proses selanjutnya yaitu pengolahan data di laboratorium bisa dilanjutkan.

\section{Tahap Analisis Data}

Dari pengolahan data tiga dimensi (3D) hasil perekaman, kemudian dilakukan analisis obyek mengenai dimensi lukisan cadas, elevasi keletakan masing-masing lukisan, kesamaan bentuk dan geometri dari gua.

\section{DAFTAR PUSTAKA}

Kawasan Karst Sangkulirang Mangkalihat

Lukisan cadas (Rock Art) merupakan salah satu 
tinggalan arkeologi yang cukup populer di dunia. Lukisan cadas (Rock Art) merupakan suatu karya manusia yang memiliki pola tertentu yang dibuat baik pada dinding gua, dinding ceruk, tebing, maupun batu besar (Tanudirjo dan Mahirta, 2009: 47). Pembuatan pola-pola gambar pada setiap objek cadas dapat dilakukan dengan beberapa cara, di antaranya menggores, mencungkil, menyemprot, dan cap. Menurut Tan (2014,73-74) gambar cadas di Asia Tenggara mulai ditemukan pada abad 19. Peneliti yang paling banyak menulis tentang gambar cadas di Asia Tenggara adalah Kusch.

Sangkulirang Mangkalihat adalah Kawasan karst yang sangat luas di Provinsi Kalimantan timur, yang di dalamnya terdapat berbagai gua yang bergambar lukisan cadas (rock art). Berdasarkan pada hasil penelitian yang pernah dilakukan, diketahui bahwa di samping lukisan cadas, pada gua-gua tersebut juga ditemukan berbagai ekofak dan artefak, yang diperkirakan berasal dari masa 4000 tahun yang lalu. Hasil temuan berupa data arkeologis tersebut, tersebar diberbagai gua di pegunungan karst, baik di kawasan Gunung Gergaji, Kawasan Muara Bulan, Kawasan Gambar Cadas Batu Kulat dan Kawasan Gambar Cadas Batu Tabalar .

\section{Perekaman Data dan Pendokumentasian Cagar Budaya}

Prosesperekamandata, sistempendokumentasian dan manajemen informasi merupakan satu kesatuan yang

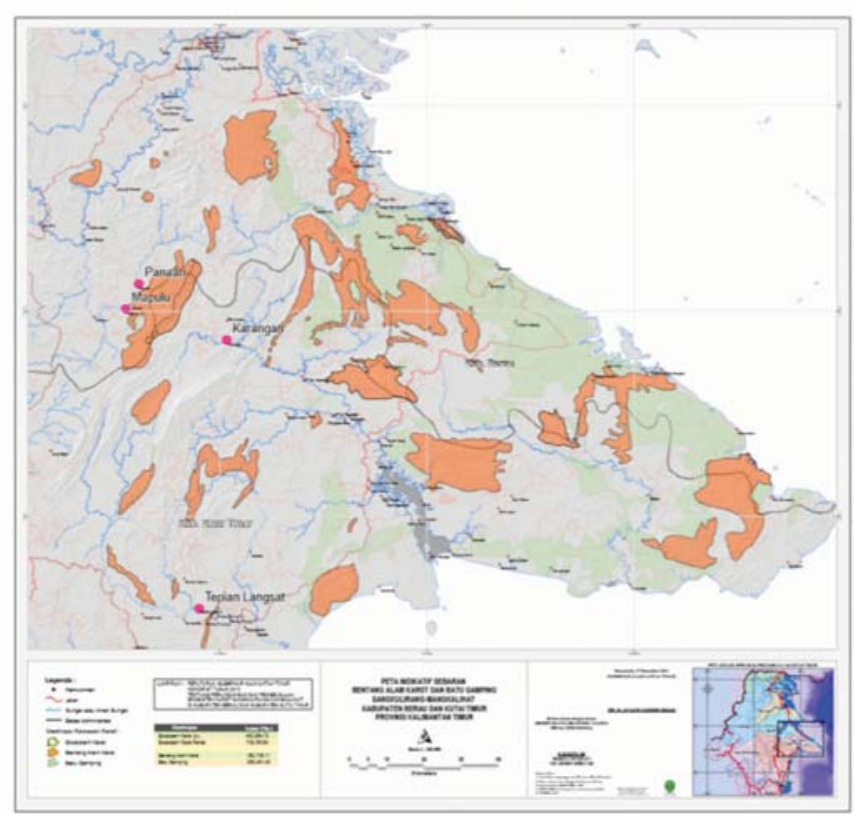

Gambar 2. Peta Sebaran Bentang Alam Karst Sangkulirang Mangkalihat tidak dapat dipisahkan. Rangkaian kegiatan tersebut digunakan sebagai salah satu usaha pelestarian dan pemeliharaan obyek Benda Cagar Budaya.

Dalam sebuah manajemen informasi dan sistem pendokumentasian obyek Benda Cagar Budaya perlu melibatkan berbagai multi disiplin ilmu untuk mendapatkan informasi yang menyeluruh dan lengkap.

Sistem pendokumentasian khususnya untuk Benda Cagar Budaya mengalami perkembangan yang cukup pesat, beberapa perkembangan sistem pendokumentasian dan perekaman data dalam rangka pelestarian Cagar Budaya antara lain :

\section{a. Sketsa dan Pencatatan Manual}

Merekam data/obyek dengan melihat langsung melalui berbagai keanekaragaman format, kemudian dituangkan dalam bentuk gambar dengan dimensi dengan akurasi yang kurang teliti. Alat yang digunakan seperti : pensil, blocknote, ballpoint.

\section{b. Hand Survey}

Teknik Perekaman dengan mengukur obyek menggunakan tangan, berdasarkan penilaian dan peralatan sederhana seperti : penggaris sederhana, meteran kecil, pensil kertas gambar.

\section{c. Photography}

Teknik Perekaman modern dengan menggunakan alat kamera disertai dengan metode khusus untuk mendapatkan data langsung dari obyek.

\section{e. Photogrammetry}

Sebuah teknik survei di mana geometri dua dimensi atau tiga-dimensi objek dapat diukur dari foto-foto yang diambil dari dua atau lebih sedikit berbeda posisi, dengan metode pengambilan foto yang disebut stereographs. Hasil data ini mampu menyediakan penampil dengan dua perspektif yang berbeda dari objek yang sama yang meniru perspektif visi teropong manusia. Pengukuran diekstrak dari stereographs, dan 3-D Informasi direkonstruksi menggunakan bebrapa instrumen perangkat keras.

\section{Terrestrial Laser Scanner 3D}

Lichti, dkk (2005) mengemukakan bahwa Terestrial Laser Scanner (TLS) merupakan suatu peralatan penangkapan gambar (image) aktif yang secara cepat dapat memperoleh kumpulan dari titik-titik tiga dimensi dari suatu objek maupun permukaan. 
Tabel 1. Kerangka Metode Pendokumentasian berdasarkan tingkat akurasi yang dihasilkan

\begin{tabular}{|c|c|c|c|}
\hline & $\begin{array}{c}\text { A } \\
\text { AKURASI RENDAH }\end{array}$ & \begin{tabular}{ll} 
B & \multicolumn{1}{c}{ AKURASI } \\
MENENGAH
\end{tabular} & $\frac{\text { C }}{\text { AKURASI TINGGI }}$ \\
\hline \multicolumn{4}{|l|}{ Manual Recording } \\
\hline & $\begin{array}{l}\text { Photo sederhana } \\
\text { Sketsa }\end{array}$ & $\begin{array}{l}\text { Photo format besar dan detail } \\
\text { Gambar tangan }\end{array}$ & $\begin{array}{l}\text { Photograph format besar } \\
\text { Photography resolusi tinggi } \\
\text { Foto Stereo Photogrammetry } \\
\text { Gambar tangan }\end{array}$ \\
\hline \multicolumn{4}{|l|}{ Digital Recording } \\
\hline Data Vektor /CAD & $\begin{array}{c}\text { Gambar AUTOCAD } \\
\text { detail ukuran } \\
\text { GPS }\end{array}$ & $\begin{array}{c}\text { Gambar AUTOCAD detail ukuran } \\
\text { autocad overlay dengan } \\
\text { photo rekonstruksi } \\
\text { GPS, 3D modeling }\end{array}$ & $\begin{array}{l}\text { DIGITAL Photogramettry } \\
\text { TOTAL STATION } \\
\text { GPS } \\
\text { 3D Modeling } \\
\text { 3D Laser Scanning }\end{array}$ \\
\hline Raster Image & $\begin{array}{l}\text { Photo DIGITAL } \\
\text { Scanning PHOTO } \\
\text { Digital VIDEO }\end{array}$ & $\begin{array}{c}\text { Photo DIGITAL } \\
\text { FOTO UDARA } \\
\text { High resolution Digital VIDEO }\end{array}$ & $\begin{array}{c}\text { Photo DIGITAL resolusi tinggi } \\
\text { FOTO UDARA } \\
\text { resolusi tinggi }\end{array}$ \\
\hline
\end{tabular}

Guiding principal of recording, documenting, the getty conservation institute , 2007

Boehler, dkk (2002) menjelaskan bahwa terdapat dua jenis scanner berdasarkan prinsip pengoperasiannya, yaitu:

1. Triangulation Scanners. Terdiri dari single camera solution dan double camera solution.

2. Ranging Scanners

a. Time of flight of a laser pulse. Laser dipancarkan ke objek selanjutnya jarak dihitung dari waktu perjalanan antara sinyal transmisi dan penerimaannya. Prinsip ini mempunyai akurasi rendah karena merupakan tipe scanner jarak jauh dengan cakupan 1,5 - 6.000 meter. Scanner jenis ini cepat dalam melakukan akuisisi data dan titik yang didapat hingga mencapai 11.000 - 122.000 titik setiap detiknya.

b. Phase comparison method. Metode ini juga sering dikenal melalui alat tacheometric. Laser yang dipancarkan dimodulasikan dengan gelombang harmonik dengan jarak yang dihitung dengan menggunakan perbedaan beda fase antara gelombang pancar dan gelombang yang diterima. Akurasi yang dihasilkan rendah karena merupakan tipe scanner jarak menengah. Akan tetapi, scanner jenis ini dapat mengukur hingga 1.000.000 titik setiap detiknya.

Spesifikasi dan prinsip kerja Terrestrial Laser Scanner 3D scanstation C 10

Scanner mengukur suatu objek sebagai point cloud. Dengan tiap point cloud merupakan jarak dari alat dan sudut horisontal/vertikal (Mendy, dkk 2011). Data yang direkam adalah data sudut horizontal $(\boldsymbol{\alpha})$, sudut vertikal (B), dan jarak antara pusat koordinat scanner dengan obyek yang direkam (R). Seperti dapat dilihat pada Gambar 1. bidang X dan Y dijadikan sebagai reference plane dalam koordinat scan. Laser bergerak dari atas ke bawah dan ke samping kanan scanner sesuai dengan arah perputaran jarum jam.

Sistem kerja dari laser ini adalah memindai permukaan obyek dengan garis vertical, sesuai dengan detil kerapatan spasi yang dibuat, data yang terekam langsung terekam dalam scan head atau bisa dikendalikan melalui laptop yang dikoneksikan melalui kabel pada perangkat laser scanner, seperti pada liustrasi gambar 4 .

\section{Registrasi Data Laser Scanner 3D}

Registrasi merupakan proses penggabungan data hasil perekaman yang didapat dari beberapa scanworld (titik

Tabel 2. Spesifikasi alat yang digunakan Leica scan station C 10

\begin{tabular}{|c|c|}
\hline \multicolumn{2}{|l|}{ SYSTEM PERFORMANCE } \\
\hline \multicolumn{2}{|c|}{ Accuracy of Single Measurement } \\
\hline Position* & $6 \mathrm{~mm}$ \\
\hline Distance* & $4 \mathrm{~mm}$ \\
\hline Angle (horizontal/vertical) & $60 \mu \mathrm{rad} / 60 \mu \mathrm{rad}(12 " / 12 ")$ \\
\hline $\begin{array}{l}\text { Modeled Surface } \\
\text { Precisin**/Noise }\end{array}$ & $2 \mathrm{~mm}$ \\
\hline Target Acquisition ${ }^{* * *}$ & $2 \mathrm{~mm}$ std. deviation \\
\hline Dual-Axis Compensator & $\begin{array}{l}\text { Selectable on/off, resolution 1" } \\
\text { Dynamic Range }+/-5 \text { ', Accuracy } 1.5 "\end{array}$ \\
\hline
\end{tabular}




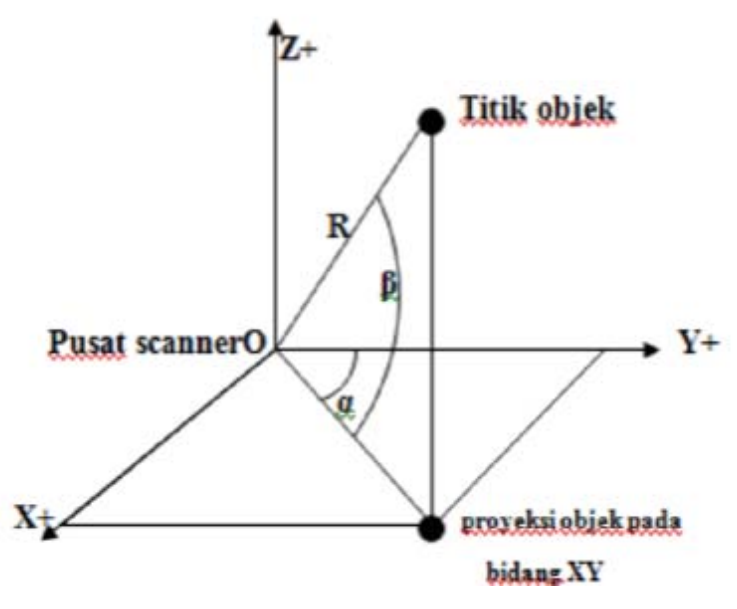

Gambar 4. llustrasi proses pemindaian Laser Scanner 3D scanstation C 10

berdiri alat) sehingga terletak dalam satu sistem koordinat (Jacob, 2005 dalam Parana, 2012). Metode registrasi yang digunakan dalam pengolahan TLS dalam penelitian ini adalah Multi Station Adjustment. Prinsip dasar dari metode ini adalah penggabungan data dari dua atau lebih posisi (scanworld) terhadap titik-titik data yang secara otomatis akan menemukan titik-titik data yang sama berdasarkan titik terdekat menggunakan proses adjustment. Algoritma dalam metode ini adalah Iterative Closest Point (ICP).

\section{PEREKAMAN DATA DI LAPANGAN}

\section{Survei dan perencanaan titik berdiri (scan world)}

Setelah dilakukan survey kondisi dilapangan kemudian diperhitungkan jumlah titik berdiri untuk bisa merekam seluruh area gua yang ada dan detail posisi lukisannya.

Dari hasil survey data tersebut kemudian dilakukan proses pemindaian tiga dimensi (3D) dengan rincian data obyek dan data teknis pengaturan alat sebagai berikut :
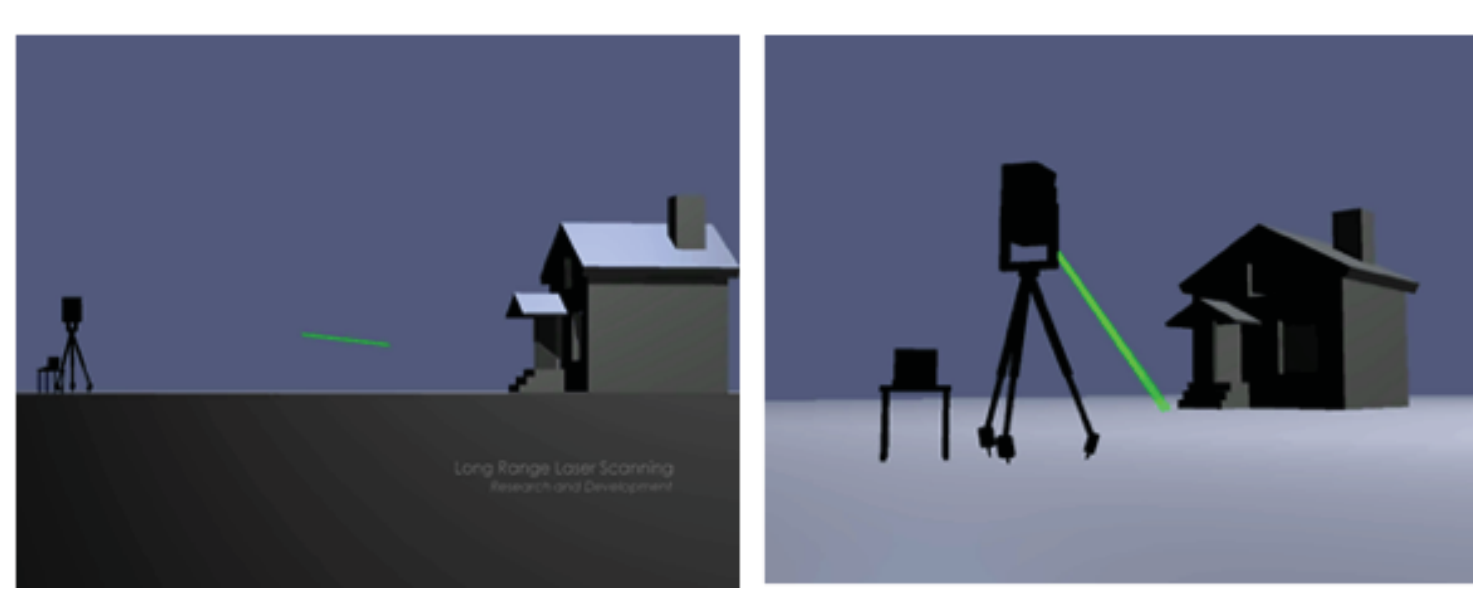

Gambar 4. Ilustrasi proses pemindaian Laser Scanner 3D scanstation C 10

\begin{tabular}{ll}
\hline DATA SITUS & Gua Tapak Tangan Mengkuris \\
\hline Nama Situs & $\begin{array}{l}\text { Desa Batulepok, Kecamatan } \\
\text { Karangan, Kabupaten Kutai Timur }\end{array}$ \\
\hline Lokasi & \\
\hline DATA TEKNIS PEMINDAIAN & \\
\hline Jumlah Station (titik berdiri) & $8 \mathrm{SW}$ (scan world) \\
\hline Jumlah Data Point & 606.397 .797 points \\
\hline $\begin{array}{l}\text { Waktu Perekaman } \\
\text { Spasi/kerapatan proses }\end{array}$ & 16 jam (2 hari) \\
\hline $\begin{array}{l}\text { scanning } \\
\text { a. Permukaan obyek }\end{array}$ & Jarak $10 \mathrm{~m} \mathrm{@} 5 \mathrm{~mm}$ \\
\hline b. Target scan & Jarak $10 \mathrm{~m} \mathrm{@} 2 \mathrm{~mm}$ \\
\hline
\end{tabular}

Delapan posisi titik berdiri scan (scan world) masing-masing memindai dengan area 360 derajad arah horizontal (dom) hal ini untuk merekam keseluruhan geometri gua dan juga detail posisi masing-masing lukisannya. Pengaturan kerapatan scan dengan besaran $5 \mathrm{~mm}$ pada jarak $10 \mathrm{~m}$ merupakan pengaturan dengan tingkat kedetilan sangat tinggi hampir mendekati tingkat kedetilan untuk akurasi pada target untuk penggabungan (registrasi) data akhir. Tingkat kerapatan yang sangat tinggi yaitu sebesar $5 \mathrm{~mm}$ mempunyai konsekuensi kapasitas data yang dihasilkan juga akan sangat besar seperti pada tabel 3 diatas menghasilkan data point sebesar 606.397.797 points, untuk itu pengolahan data (post processing) juga memerlukan perangkat computer yang mempunyai spesifikasi yang tinggi.

Gua Tapak Tangan Mengkuris mempunyai struktur geometri ruang dalam yang terbuka dan tidak begitu banyak lekukan, sehingga lebih memudahkan dalam proses pemindaian 3D, sedangkan posisi panel lukisan yang ada tersebar dari balkon atas sampai pada ruang bawah gua. 


\section{Proses pemindaian (scanning) Gua}

Tahap pemindaian (scanning) lukisan cadas dilakukan melalui tiga (3) tahapan, yaitu :

1. Pemotretan citra obyek $360^{\circ}$ (Acquire Photo Image)

Proses pengenalan obyek yang dilakukan dengan

Pemotretan citra obyek. Hasil yang dapat dilihat pada proses ini adalah hasil foto dengan dimensi keliling sampai $360^{\circ}$ untuk arah horisontal dan $270^{\circ}$ untuk arah vertical

\section{Pemindaian 3D (scanning)}

Merupakan proses inti dari Pemindaian 3D dimana instrument Laser Scanner melakukan perekaman terhadap surface obyek dengan pemindaian laser yang kemudian tersimpan dalam data point (Point Clouds) berkoordinat $(\mathrm{x}, \mathrm{y}, \mathrm{z})$. Bagian obyek yang akan di scan dapat disetting sesuai dengan keinginan kita . Untuk setingan kerapatan point dapat dilakukan sampai dengan spasi $2 \mathrm{~mm}$, semakian kecil/rapat setingan spasi yang kita lakukan maka data akan semakin kompleks dan detail, jumlah point yang dihasilkan akan semakian besar dan waktu yang dibutuhkan pun akan semakin lama.

\section{Pemindaian Target (scanning target)}

Proses pemindaian target ini merupakan satu tahapan yang sangat penting karena metode penggabungan (registrasi) yang akan digunakan adalah dengan menggunakan target (target to target) sehingga diperlukan data scanning target yang akurat.

\section{Penggabungan data scan (registrasi)}

Proses penggabungan data scan (registrasi) ini dilakukan untuk menggabungkan data scan dari bebrapa

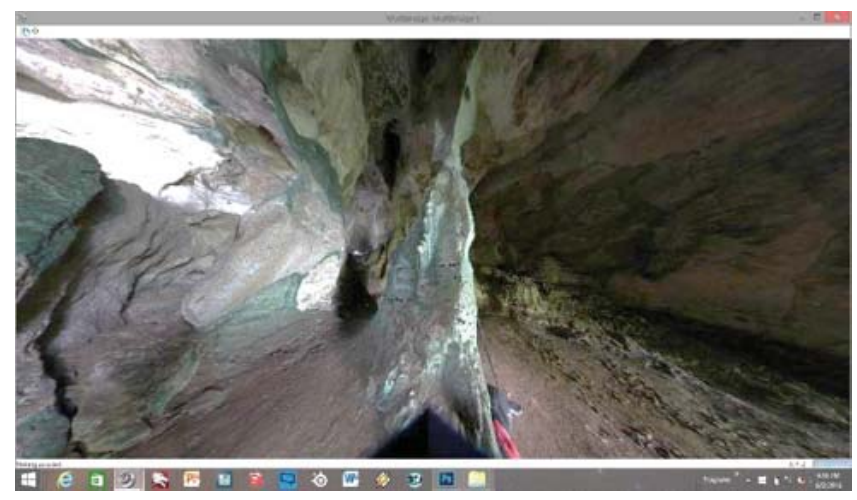

Gambar 5. Hasil Acquire Photo Image

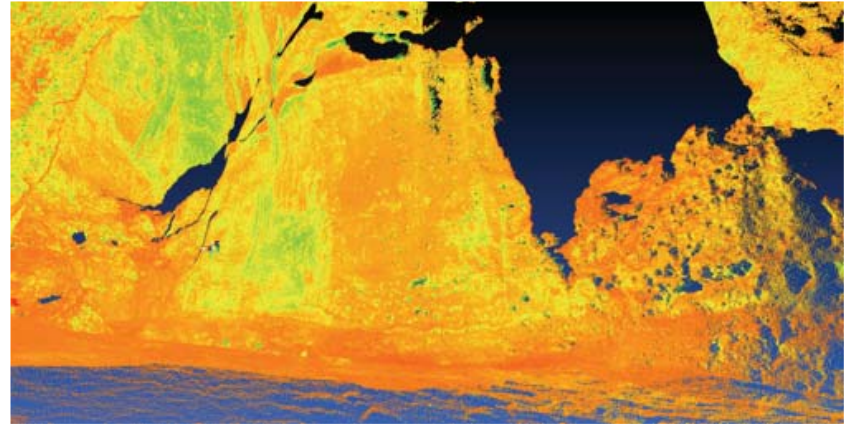

Gambar 6. Satu sampel hasil pemindaian 3D

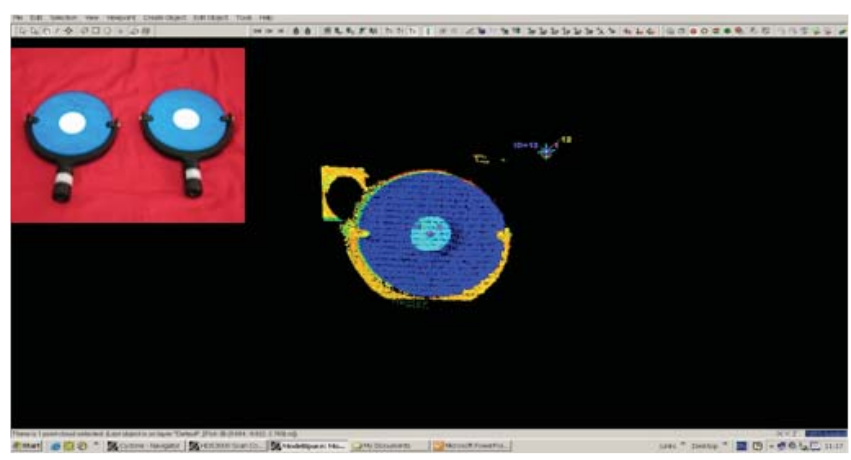

Gambar 7. Hasil scanning target dengan kerapatan spasi $2 \mathrm{~mm}$

sudut gua sehingga didapatkan satu kesatuan data tiga dimensi (3D) yang utuh dan akurat.

Pada proses pemindaian 3D (scanning) ini metode penggabungan yang digunakan adalah dengan metode menggunakan target (target to target). Disamping metode penggabungan menggunakan target ada beberapa metode lain yang bisa digunakan yaitu :

1. Metode cloud to cloud

Titik ikat yang digunakan untuk registrasi didapat dari titik - titik objek hasil perekaman sehingga pada saat perekaman target tidak perlu pemasangan target. Syarat agar scanworld dapat diregistrasi, maka antar scanworld harus memiliki pertampalan minimum sebesar $20 \%$ dari daerah yang direkam. Kekurangan untuk metode ini kualitas registrasinya paling rendah dibanding dengan metode lainnya.

2. Metode Visual Aligment

Visual dari masing masing posisi titik berdiri alat merupakan unsur yang penting dari metode ini, dan hasil pertampalan secara visual minimal $80 \%$, hampir sama dengan prinsip pada fotogrametri rentang dekat (close range fotogrametry), hal ini sangat akan berpengaruh terhadap hasil registrasi. Dibandingkan dengan metode target to target metode ini mempunyai tingkat kualitas akurasi yang lebih rendah.

Metode target to target yang digunakan pada 
proses perekaman ini dengan memasang target sebanyak 4 buah, target minimal yang bisa digunakan adalah sebanyak 3 buah, tambah 1 target tetap digunakan untuk mengantisipasi eror yang dihasilkan pada salah satu target.

Dari proses registrasi dengan software cyclone 9.0 didapatkan tingkat eror yang cukup rendah dengan nilai hampir keseluruhan dibawah $2 \mathrm{~mm}$ sehingga hasil penggabungan data keseluruhan mempunyai tingkat akurasi yang sangat tinggi, untuk rincian tingkat eror dari masing masing target adalah sebagai berikut :

Tabel 4. Nilai eror prose penggabungan (registrasi) data scan Gua Tapak Tangan Mengkuris

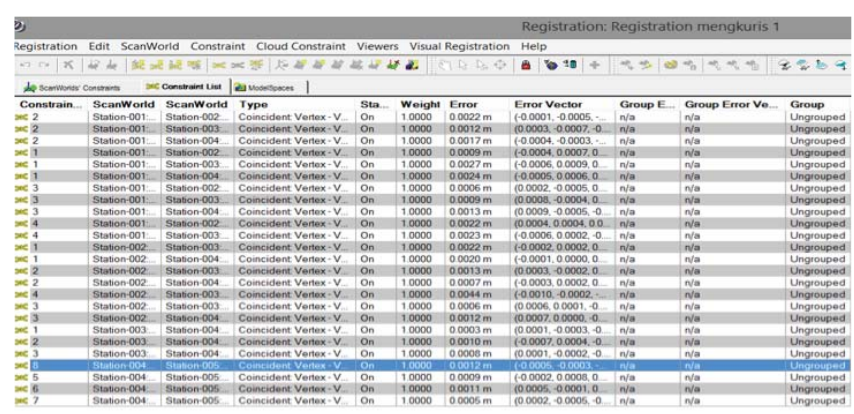

\section{PENGOLAHAN DATA DAN ANALISA}

\section{Pengolahan data scan}

Proses pengolahan data menggunakan beberapa perangkat lunak (software) seperi cyclone 9.0, Autocad 2015, dan 3D Reshaper. Dari proses pengolahan data ini akan menghasilkan beberapa output dan produk antara lain :

1. Gambar (drawing) 2D

Yang terdiri dari : Gambar Tampak, Gambar Potongan dan denah situasi

Dari gambar 8,9 dan 10 yang merupakan data gambar dua dimensi (2D) bisa diketahui denah gua, potongan melintang dan data perbedaan elevasi pada masing-masing ruang yang ada didalam gua.

2. Gambar/citra 3D (3D model image point clouds)

Format : tiff, bmp dan jpeg

Gambar 11,12 dan 13 merupakan data gambar tiga dimensi (3D) keseluruhan bentuk geometri gua dan posisi masing-masing lukisan cadas yang ada. Dari hasil data ini bisa diketahui dengan mudah dimensi dari gua itu. Dalam tahapan analisis selanjutnya dari data ini juga bisa dibuat kontur (gambar 18) dan digital surface model (DSM) (gambar 17).

Gambar 15 dan 16 menunjukan posisi keletakan

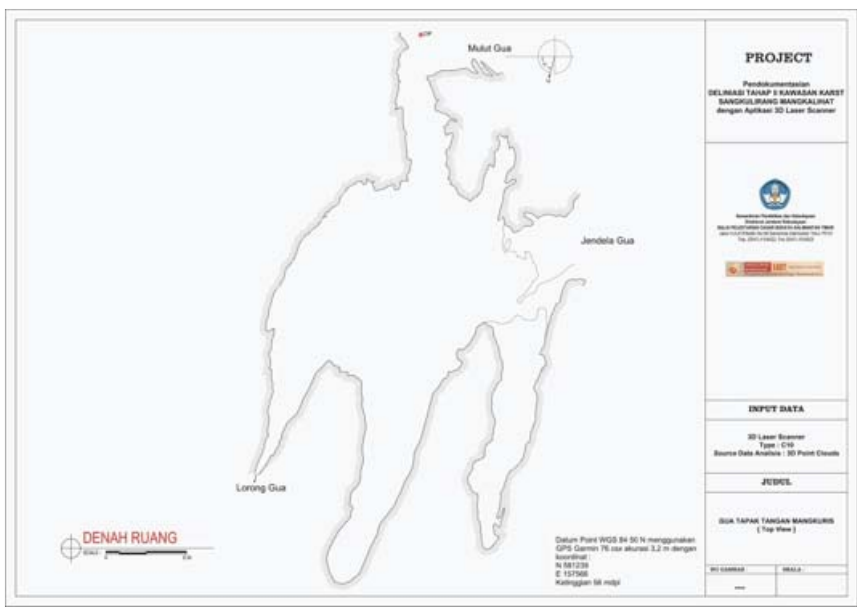

Gambar 8. Denah Ruang Gua Mengkuris

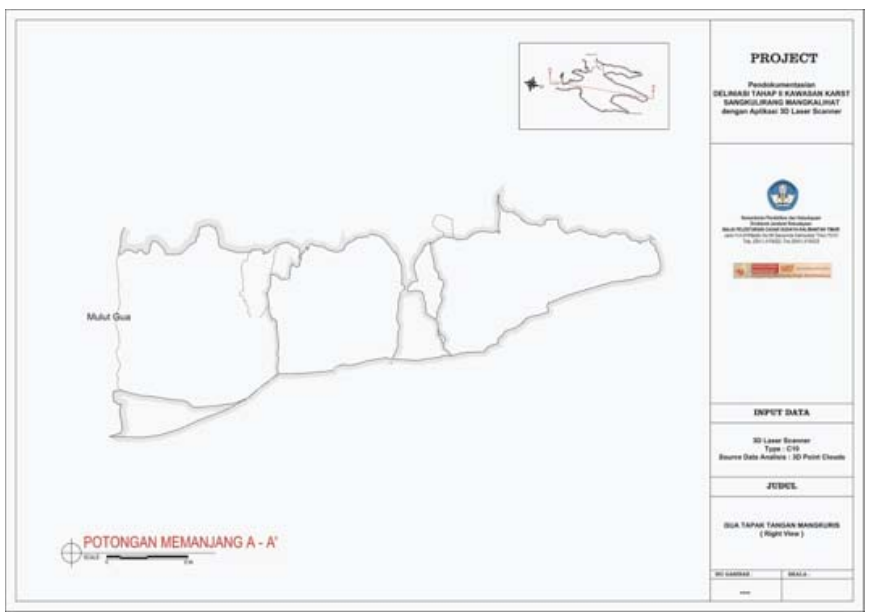

Gambar 9. Gambar Potongan Memanjang A-A'

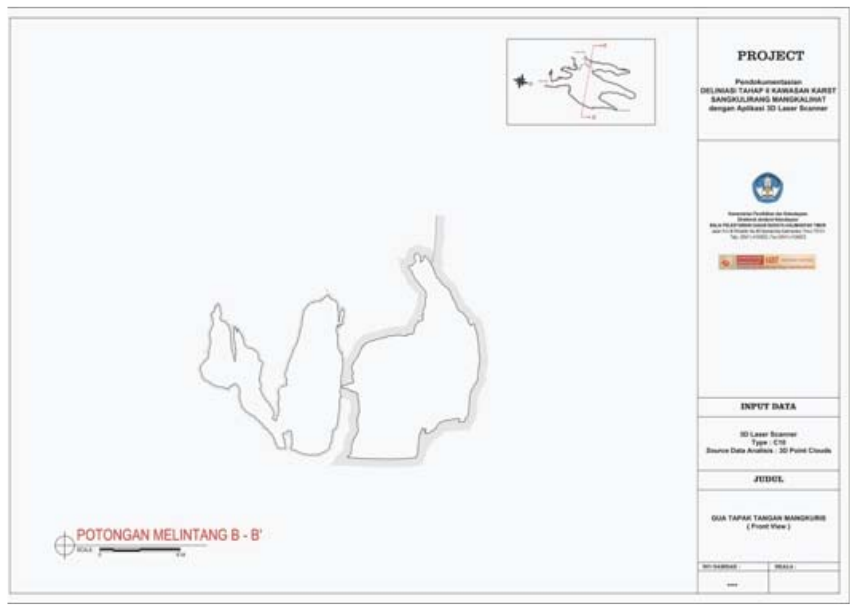

Gambar 10. Gambar Potongan Melintang B-B'

lukisan secara detail, posisi keletakan ini ditunukan dalam besaran koordinat $(\mathrm{x}, \mathrm{y}, \mathrm{z})$ dari datum point yang sudah ditentukan. Dari gambar tersebut (15 dan 16) juga bisa dilihat secara detail bentuk lukisan dan ukuran masing-masing jari. 


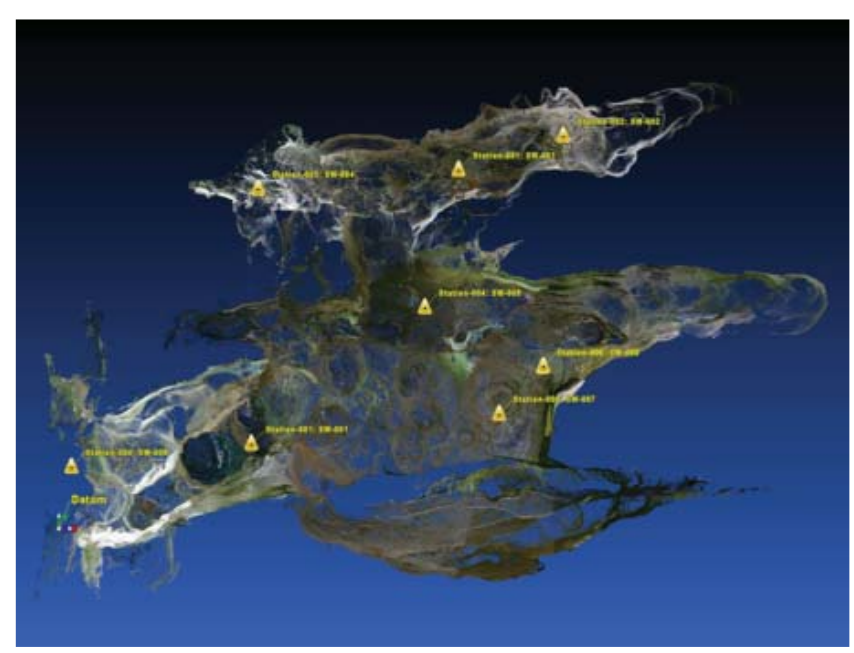

Gambar 11. hasil model 3D posisi titik berdiri (scan world)

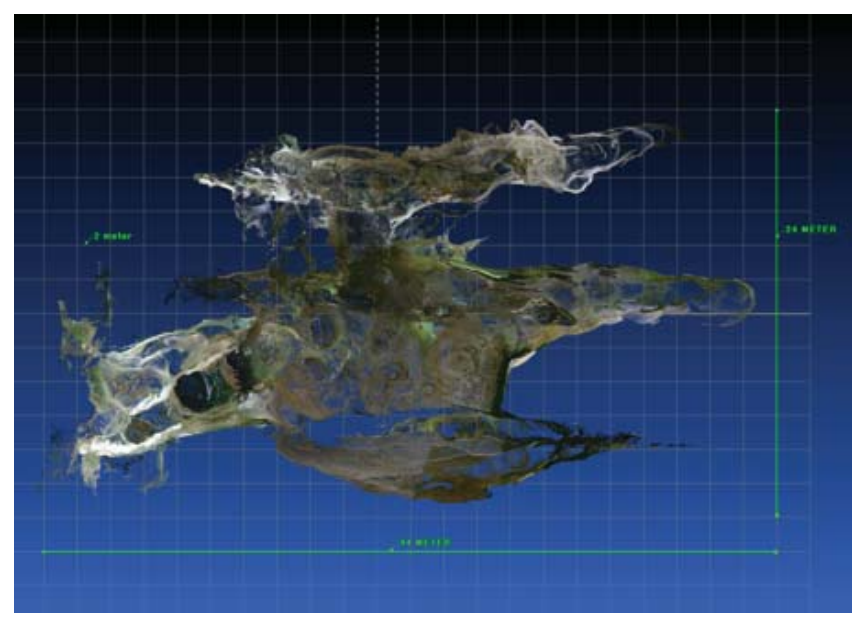

Gambar 12. hasil model 3D tampak atas (colour from scanner)

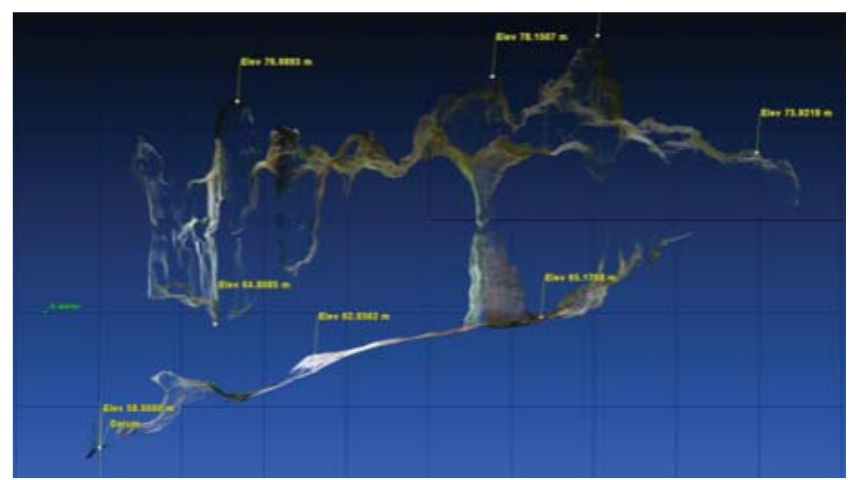

Gambar 13. hasil model 3D potongan memanjang (colour from scanner)

3. DSM (Digital Surface Model) dan kontur

Salah satu output dan produk lain yang bisa dihasilkan dari pengolahan data scan 3D ini adalah DSM (Digital Surface Model) dan kontur. Data DSM (Digital Surface Model) cukup efektiv untuk digunakan sebagai visualisasi model untuk mengetahui beda tinggi yang terbentuk dalam perbedaan chart warna, sedangkan

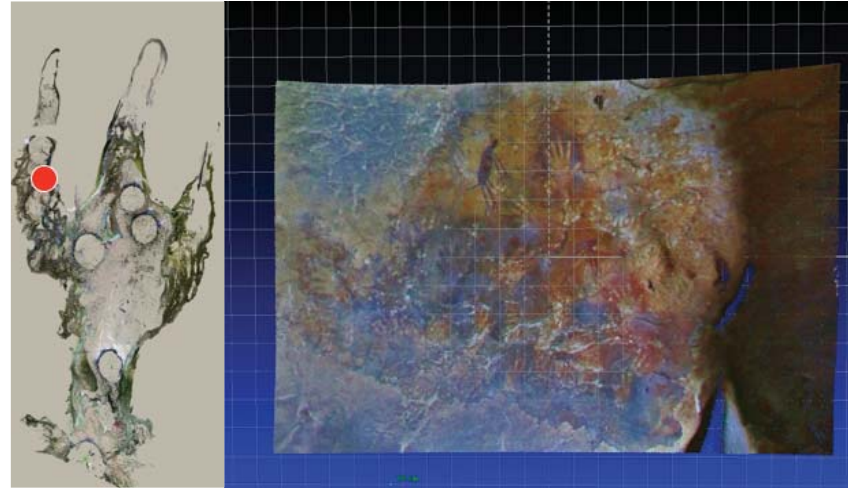

Gambar 14. Detail model 3D lukisan panel 1

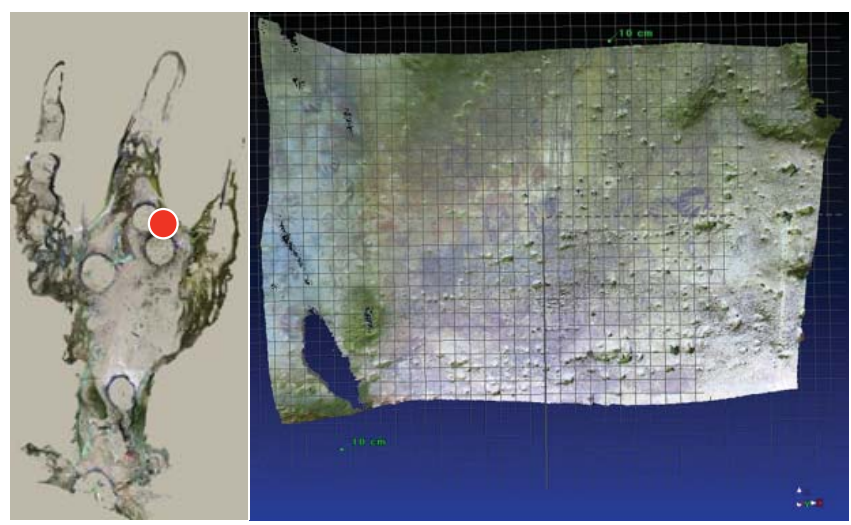

Gambar 15. Detail model 3D lukisan panel 2

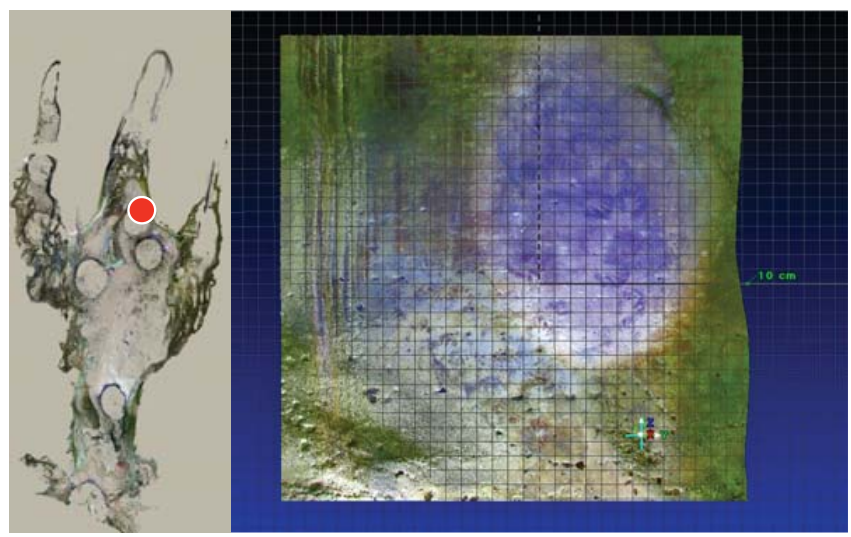

Gambar 16. Detail model 3D lukisan panel 3

untuk data kontur yang dihasilkan sangat detail bisa dibuat dengan internal dalam $\mathrm{cm}$. file yang dihasilkan dalam format : mesh dan dwg; dxf

4. Animasi (fly through animation)

Format data : avi

Gambar 19 merupakan hasil pengolahan data dalam bentuk animasi dengan format avi. Hasil animasi ini cukup informative digunakan sebaggai visualisasi dalam rangka penyebaran informasi kepada masyarakat luas tentang detail bentuk gua dan lukisan yang ada di dalamnya. 


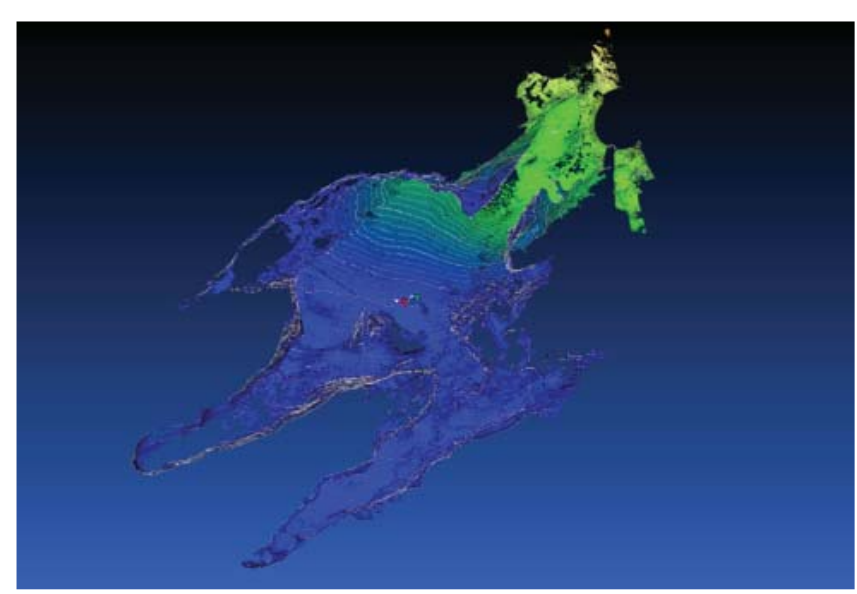

Gambar 17. Hasil model 3D dalam format DSM

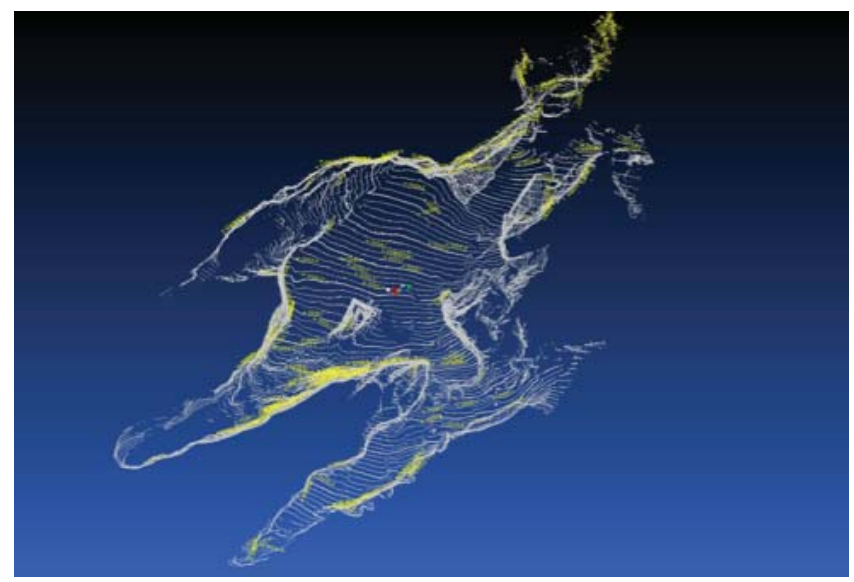

Gambar 18. Hasil data kontur interval $25 \mathrm{~cm}$

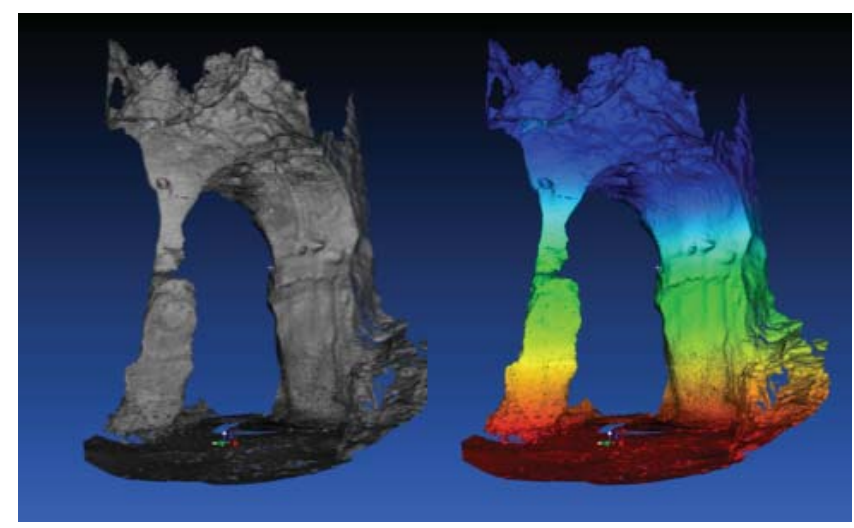

Gambar 19. Hasil data DSM bagian Pilar

\section{Virtual tour $360^{\circ}$}

Operasional dengan aplikasi IE (internet explorer) Hasil data berupa virtual tour $360^{\circ}$ pada gambar 20 diatas merupakan media yang tidak kalah menarik yang bisa digunakan sebagai media interaktif publikasi, selain sebagai media interaktif data virtual tour ini juga bisa digunakan sebagai referensi dan acuan data karena dari aplikasi ini juga bisa diketahui secara langsung posisi, ukuran dan bentuk dari masing-masing lukisan yang ada.

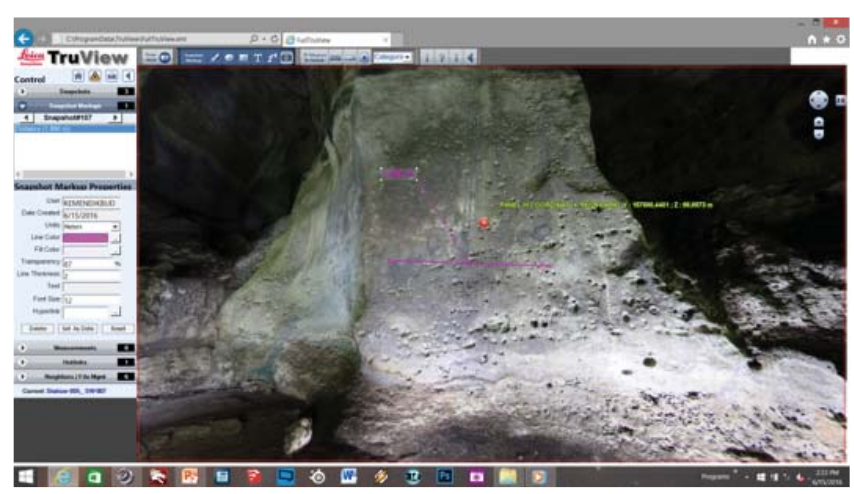

Gambar 20. Output data berupa aplikasi virtual tour $360^{\circ}$

\section{Analisa Data}

Proses perekaman data dengan teknologi laser scanner 3D untuk sasaran obyek Gua Tapak tangan Mengkuris dilakukan dalam waktu 2 hari dengan estimasi operasional perekaman perharinya selama 8 jam, dan selama 8 jam alat melakukan proses pemindaian secara terus menerus. Proses registrasi dengan metode target to target menghasilkan eror yang sangat rendah, hampir semua titik beridir (scan world) dibawah $2 \mathrm{~mm}$. Pengaturan spasi kerapatan scan sebesar $5 \mathrm{~mm}$ merupakan pengaturan dengan tingkat kedetailan sangat tinggi. Dari pengolahan data pemindaian 3D menghasilkan beberapa output yang cukup signifikan untuk perolehan data dalam format $2 \mathrm{D}$ dan 3D, termasuk juga animasi visual dan virtual tour. Dari analisa waktu yang dibutuhkan untuk melakukan perekaman data lukisan cadas (Rock Art), metode menggunakan Terrestrial Laser Scanner ini hanya membutuhkan waktu yang cukup pendek hanya dengan waktu 2 hari menhasilkan beberapa output dan produk yang cukup banyak dengan tingkat akurasi yang sangat tinggi.

\section{KESIMPULAN DAN SARAN}

\section{Kesimpulan}

Berdasarkan hasil analisa data perekaman lukisan cadas (Rock Art) pada Gua Tapak Tangan Mengkuris, di kawasan Karst Sangkulirang Mangkalihat dapat diambil beberapa kesimpulan yaitu :

1. Terestrial Laser Scanner 3D sangat efektif untuk digunakan sebagai perangkat dan metode perekaman data tiga dimensi (3D) pada lukisan gua (Rock, Art).

2. Efektifitas dari penggunaan perangkat Terestrial Laser Scanner 3D untuk perekaman data lukisan gua (Rock Art) ini bisa dilihat dari analisa kebutuhan waktu untuk proses perekaman, tingkat akurasi dan 
ketelitian data dan produk atau output data yang bisa dihasilkan.

3. Nilai akurasi yang dihasilkan dari proses registrasi data point menghasilkan nilai akurasi yang sangat tinggi dari semua sudut dan titik berdiri (scan world) menghasilkan nilai eror rata-rata dibawah $2 \mathrm{~mm}$, nilai eror tersebut masih sangat baik dibandingkan dengan eror yang dihasilkan oleh laser distometer dengan nilai sebesar $9 \mathrm{~mm}$

\section{Saran}

Beberapa masukan yang bisa disampaikan dari hasil evaluasi dan analisa data penelitian antara lain :

1. Metode perekaman data Cagar Budaya khususnya lukisan cadas (Rock Art) dalam format 3D sangatlah penting sebagai data dan acuan untuk penanganan konservasi dan monitoring. Terestrial Laser Scanner

\section{DAFTAR PUSTAKA}

Aronaff. 1989. Geographic Information System : A Management Perspective. Ottawa Kanada : WDLPublication

Ford, D. \& Williams, P. 2007. Karst Hydrogeology and Geomorphology. John Wiley \& Sons, Ltd., $562 \mathrm{p}$.

Pearson, Michael \& Sharon Sullivan. 1995

Looking After Heritage Places. Melbourne : Melbourne Universty Press

Permana, R. Cecap Eka, 2008. Pola Gambar Tangan Pada Gua-gua Prasejarah Di Wilayah Pangep-Maros Sulawesi Selatan. Disertasi Depok : Universitas Indonesia

Samodra, Hanang, 2001. Nilai Strategis Kawasan Kars di Indoensia, Pengelolaan dan Perlindungannya. Balitbang ESDM Departemen ESDM, Bandung.
3D merupakan salah satu metode yang sangat efektif untuk digunakan, namun penggunaan alat ini masih sangatlah terbatas dikarenakan faktor mahalnya alat. Untuk itu perlu dilakukan penelitian untuk pengembangan teknologi perekaman data berbasis 3D dengan metode lain yang lebih murah, efisien namun akurasinya tetap bisa dipertanggung jawabkan.

2. Hasil/output data dari perekaman 3D gua ini menghasilkan data koordinat $\mathrm{x}, \mathrm{y}, \mathrm{z}$ yang akurasinya sangat tinggi, format data yang dihasilkan ini bisa digunakan sebagai data untuk pembuatan maket atau prototype dengan skala yang sangat mudah untuk diatur. Untuk itu perlu kiranya untuk program pelestarian dan pengembangan informasi lukisan cadas ini dibuat maket atau prototype berdasarkan data Laser Scanner 3D

Robin Leteiler, 2007. Recording, Documentation and Information Management for the Conservation of Heriatge Places, The Getty Conservation Institute.

Boyd, Carolyn E, 2003. Rock Art of the Lower Pecos, College Station, Texas A\&M University Express

Diego Gonzales_Aquilera, Angel Munoz Nieto, Javier Gomez Lahoz, Jesus Herrero, Gabriel Guiterez Alonso, 2009 3D Digital Surveying and Modeling of Cave Geometry : Application to Paleolithic Rock Art, Sensors Journal.

The ISPRS International Archives of the Photogrametry, Remote Sensing and Spatial Information Sciences, Volume XXXVIII-5/c.19 ISSN 1682 1750, sries 1, 2007 \& 2009. CIPA Heritage Documentation Best Practices and Aplication. ICOMOS 